\title{
Otoacoustic emissions in young adults exposed to drums noise of a college band
}

\author{
Paula Botelho da Silva(1) \\ Ana Cláudia Fiorini ${ }^{(1)}$ \\ Marisa Frasson de Azevedo(1)
}

\begin{abstract}
(1) Universidade Federal de São Paulo UNIFESP/EPM - São Paulo/SP - Brazil.

Conflict of interest: Nonexistent
\end{abstract}

Received on: February 08, 2017 Accepted on: August 10, 2017

Mailing address:

Paula Botelho da Silva

Rua Coronel Carlos Ambrogi, 235 -

Pirituba, São Paulo, São Paulo, Brasil CEP: 02969-130

E-mail: paulabot.silva@hotmail.com

\section{ABSTRACT}

Purpose: to identify cochlear dysfunction and occurrence of tinnitus in young adults exposed to drums noise of a college band.

Methods: the sample included 50 subjects: 25 musicians (study group) and 25 non-musicians (control group). The procedures included anamnesis, pure tone audiometry, acoustic impedance and Transient Evoked Otoacoustic Emissions, Distortion Product Otoacoustic Emissions and Distortion Product Otoacoustic Emissions InputOutput function.

Results: positive correlation between the occurrence of tinnitus and the variables exposure time and use of personal stereos was found. Overall, the study group showed significantly lower Transient Evoked Otoacoustic Emissions, when compared to the control group. In the study group, there was a tendency toward worse response in $6 \mathrm{kHz}(\mathrm{f} 2)$ in Distortion Product Otoacoustic Emissions in both ears. The Distortion Product Otoacoustic Emissions Input-Output function did not differ between groups nor did its slope.

Conclusion: in general, otoacoustic emissions were worse in noise-exposed young people (study group) when compared to the unexposed (control group), indicating that the test may be important in early identification of cochlear changes.

Keywords: Noise; Hearing; Music; Hair Cells, Auditory 


\section{INTRODUCTION}

Recent research has shown that non-occupational noise exposure can cause damage to the auditory system.

Several studies relate and demonstrate the importance of the use of otoacoustic emissions (OAE) for the prevention and diagnosis of hearing loss in individuals exposed to noise, as they may present cochlear dysfunction despite a normal audiogram ' .

The OAE are sounds that are generated spontaneously or not in the hair cells of the inner ear, travel to the middle ear into the ear canal where they can be measured by a microphone. Therefore, the middle ear must be intact so that the sounds coming from the cochlea may be captured in ear canal ${ }^{2-4}$.

The DPOAE arise from the non-linear integration of two simultaneous pure tones presented to the cochlea. The two tones have two different frequencies ( $f 1$ e f2), which are denominated primary frequencies. The best results are found in the frequency equivalent to $2 \mathrm{f} 1$ $\mathrm{f} 2$, in the relation $\mathrm{f} 2 / \mathrm{f} 1$ of $1,22^{5,6}$.

The DPOAE may be obtained in different ways ${ }^{7-9}$ : DP Gram which shows the range of the emissions in several frequencies in a previously determined sound level; DP Growth Rate also known as DPOAE I/O (input/output) in which the responses are analyzed in a particular frequency in decreasing sound levels in order to find the threshold of the response to the presented stimulus and provide information on cochlear non- linearity.

Research concerning $\mathrm{OAE}$, show the non-linearity of the cochlea, essential for a normal hearing function, cochlear compression and functioning of the external hair cells ${ }^{8,10-12}$. OAE are recommended to evaluate individuals exposed to noise in order to identify as early as possible alterations and /or to assess the progression of an already acquired hearing loss ${ }^{1,13}$. The reduction of the DPOAE after exposure to noise is described in the literature ${ }^{14}$, especially in the 5 and 6 $\mathrm{kHz}$. Many studies show the possible use of the DPOAE I/O as an indirect measure of human cochlear nonlinearity ${ }^{15,16}$. The slope of the function can be evaluated and a threshold can be determined, as an additional procedure to check hearing function $6,11,17$. Threshold is defined as the lowest stimulus level producing a DPOAE that is $3 \mathrm{~dB}$ above the noise floor ${ }^{9}$.

The growth rate may be measured in three different ways: area, slope or threshold. The area is the difference between response and noise floor. This measure provides the cochlear amplification mechanism 9 . The slope inclination shows the cochlear nonlinearity: the slope decreases with the rise of the sound level. This reduction rate corresponds to the compression region of the growth rate and goes up to $80 \mathrm{dBSPL}$. The compression can be estimated as the difference between the low level threshold and high level maximum inclination ${ }^{15}$. The more acute the cochlear lesions, the less inclined the slope ${ }^{18,19}$.

In teenagers with or without tinnitus, the high frequency audiometry and the TEOAE (up to $4.000 \mathrm{~Hz}$ ) and DPOAE (up to $12.000 \mathrm{~Hz}$ ) did not show statistically significant difference in the cochlear responses, thus suggesting that the external hair cells of teenagers with tinnitus might not be sufficiently damage to cause hearing impairment. The noise exposure time may be an important factor, since adults with tinnitus show hearing impairment. The use of personal stereos and noise exposure reduce otoaocustic emissions, despite there are being statistical difference ${ }^{20}$.

Given that OAEs may show a trace of alteration even in subjects with normal thresholds if the audiogram is within the normal standards,

The importance of researching the OAEs in noise exposed young adults is based on the possibility of early identification even before a noise induced hearing loss can be detected in an audiogram.

Thus, the goal of the present study was to identify cochlear dysfunction and tinnitus in young adults exposed to noise of the college drum band

\section{METHODS}

Observational and cross-sectional survey approved by the Research Ethics Committee of Universidade Federal de São Paulo (UNIFESP), under protocol 542.452. The study procedures were explained verbally to participants, and those who agreed to participate signed the free informed consent. This study was conducted in the clinic of audiology of UNIFESP.

The sample was composed of 50 college students divided into two groups. The study group consisted of 25 students who participated in the college drum band. A control group with 25 students who did not participate in the band was composed. The groups were matched by gender and age, tested by ANOVA. The two groups aged 18 to 30 years should present normal otoscopy and tympanometric curve type $A^{21}$. Students with conductive hearing loss at the time of collection, previous exposure to occupational noises and history of metabolic or genetic diseases were excluded. 
The musical instruments used in the band are drums, percussion, tambourine, repinique and ganzá. During the rehearsals, a single exploratory noise measurement was carried out of the college band using the cellphone app Decibelímetro $H Q$ positioned at the height of the participants' ears. Three measurements were made, composed of twelve samples each, made during one minute, every five seconds ${ }^{22}$. The average values of the sound pressure levels obtained in the three measurements were, respectively: 96.2; 94.2; and 98.8 dBA.

Anamnesis was conducted to obtain data relate to hearing complaints, individual's history in the band, general health data and use of personal stereos which also may interfere in the cochlear function.

Tests of Transient-evoked Otoacoustic Emissions (TEOAE) and of Distortion-product Otoacoustic Emissions (DPOAE) were performed with ILO UBS-V6. The equipment has a probe which was positioned in external acoustic meatus of the individual. In TEOAE, a probe was used to present the non-linear stimulus covering a frequency range from $500 \mathrm{~Hz}$ to $4 \mathrm{kHz}$ (both ears alternately) with levels ranging from 75 to $85 \mathrm{dBSPL}$. Responses at frequency ranges of 1,000, 1,500, 2,000, 3,000 and 4,000 Hz were investigated. The criterion used for analysis of presence was a response in dBSPL (signal to noise ratio) greater than or equal to $3 \mathrm{~dB}$ NPS, in each frequency range tested, general reproducibility greater than $50 \%$ and probe stability greater than or equal to $70 \%{ }^{23}$.

DPOAEs was evoked in the f2(s) from $1000 \mathrm{~Hz}$ to $6000 \mathrm{~Hz}$ with $\mathrm{L} 1=65$ e $\mathrm{L} 2=55 \mathrm{dBSPL}$. The criterion used to indicate the presence of DPOAEs was a response in $\mathrm{dBSPL}$ at least $6 \mathrm{~dB}$ above the first standard deviation of the equivalent noise, at each $\mathrm{f} 2$ tested ${ }^{23}$.

The growth rate was obtained in the frequencies of $2 \mathrm{k}, 3 \mathrm{k}, 4 \mathrm{k}$ and $6 \mathrm{kHz}$, registering the emissions responses due to the reduction of the levels of sound pressure in each frequency. The threshold of the DPOAE was considered as the lowest sound pressure level with the signal to noise ratio greater than $3 \mathrm{~dB}^{24}$. The stimuli $\mathrm{f} 2$ (L2) were presented with the variation of 20 to $65 \mathrm{~dB}$ SPL in steps of $5 \mathrm{~dB}$, and the stimulus level f1 (L1) was carried based on the equation proposed by Kummer et al (1998), that is: $L 1=0,4 \mathrm{~L} 2+39 \mathrm{~dB}$. The Slope was registered and compared between the groups so that one could measure the inclination of the of the responses of the growth rate.

A one-way ANOVA was performed in order to compare to compare age between the groups, otoacoustic emissions responses, thresholds and Slope. The Spearman Test was also used to verify correlations between the questionnaire variables and the OAEs responses. The $p$ value less than 0.05 was considered significant.

\section{RESULTS}

The study group and the control group had more women, 88\%, because they attended a course, Audiology and Speech Therapy, mostly attended by women. The average age of the control group was 20.5 years and of the study one was 20.6 years, with no difference between the groups ( $p=0.849$ - ANOVA). Most of the subjects ( $76 \%$ control and $60 \%$ study) did not suffer from otitis. Those who did had it in childhood (75\%).Most did not present tinnitus (80\% CG e 64\% EG). When there was tinnitus, in most (92.3\%) it was sporadic and high-pitched. Of the assessed individuals, $78 \%$ used personal stereos, of which $60.5 \%$ for a period of up to 30 minutes a day, $31.6 \%$ from 30 to 60 minutes and $7.9 \%$, for 60 minutes or more.

The average time of participation in the drums band was one year and 92 days. Regarding the rehearsal, in average, they rehearsed for a day and half per week, lasting an hour and a half. Most of the participants did not use an earplug (Table 1).

Spearman's correlation analysis was done to verify correlations between the data of the questionnaires. There was a positive correlation between the incidence of tinnitus (frequency and form) and the variable time in the drum band and rehearsal days and hours. Thus, the greater the number of days, time and hours of rehearsal in the drums band, the more frequent the tinnitus. There was also correlation between the use of personal stereos and tinnitus, as the more these devices were used, the greater the occurrence of tinnitus (Table 2). 
Table 1. Distribution of time on the college drum band, days and hours of rehearsal and the use of hearing protector in the study group $(n=20)$

\begin{tabular}{|c|c|c|c|c|c|}
\hline Variable & & $\mathrm{n}$ & $\%$ & Average & Standard Deviation \\
\hline \multirow{3}{*}{ Time on the band } & $1-12$ months & 9 & 36 & \multirow{3}{*}{1.92} & \multirow{3}{*}{0.812} \\
\hline & $12-24$ months & 9 & 36 & & \\
\hline & 25 or more & 7 & 28 & & \\
\hline \multirow{3}{*}{ Rehearsal days } & 1 & 15 & 60 & \multirow{3}{*}{1.56} & \multirow{3}{*}{0.870} \\
\hline & 2 & 8 & 32 & & \\
\hline & 4 & 2 & 8 & & \\
\hline \multirow{2}{*}{ Rehearsal hours } & 1 & 18 & 72 & \multirow{2}{*}{1.28} & \multirow{2}{*}{0.458} \\
\hline & 2 & 7 & 28 & & \\
\hline Hearing Protector & yes & 5 & $\begin{array}{l}20 \\
80\end{array}$ & 1.80 & 0.408 \\
\hline
\end{tabular}

Table 2. Distribution of the correlation data among the variables of the questionnaire

\begin{tabular}{ccccccccc}
\hline Variable & & Otitis & Tinnitus & $\begin{array}{c}\text { Personal } \\
\text { Stereos }\end{array}$ & $\begin{array}{c}\text { Time on the } \\
\text { band }\end{array}$ & Days & Hours & $\begin{array}{c}\text { Hearing } \\
\text { Protector }\end{array}$ \\
\hline Tinnitus & $\mathrm{r}_{\mathrm{s}}$ & -0.16 & .997 & .126 & .358 & .175 & .338 & .627 \\
Frequency & $\mathrm{p}$ & 913 & $.000^{* *}$ & .388 & $0.79^{*}$ & .403 & $.098^{*}$ & $.001^{* *}$ \\
\hline Personal & $\mathrm{r}_{\mathrm{s}}$ & .157 & .116 & - & .179 & .315 & .067 & .047 \\
Stereos & $\mathrm{p}$ & .275 & .422 & - & .191 & .126 & .751 & .824 \\
\cline { 2 - 9 } Time with the & $\mathrm{r}_{\mathrm{s}}$ & -.289 & .344 & .179 & - & .345 & .512 & .079 \\
band & $\mathrm{p}$ & .162 & .092 & .191 & - & $.091^{*}$ & $.009^{*}$ & .726 \\
\cline { 2 - 9 } Rehearsal & $\mathrm{r}_{\mathrm{s}}$ & .052 & .0140 & .315 & .345 & - & .463 & -.152 \\
days & $\mathrm{p}$ & .804 & .505 & .126 & $.091^{*}$ & - & .020 & .468 \\
\cline { 2 - 9 } Hours & $\mathrm{r}_{\mathrm{s}}$ & .052 & .282 & .067 & .512 & .463 & - & .089 \\
& & .804 & .172 & .751 & $.009^{*}$ & .020 & - & .672 \\
\hline
\end{tabular}

Statistical method: correlation test of Spearman

In the comparison between the groups, there was smaller general response to TEOAE in the study group in both ears (Table 3 ), with a significant difference between the groups (ANOVA). There was no statistically significant difference between the groups when compared by frequency bands.
Regarding the DPOAE in the frequency of $6,000 \mathrm{~Hz}$ in both ears, there was a tendency of the control group to present better response (Table 4).

Table 3. Distribution of general responses of TEOAE

\begin{tabular}{cccccccc}
\hline Variables & Groups & Mean & SD & Minimum & Maximum & F & P value \\
\hline TEOAE & Study & 20.41 & 5.26 & 12.3 & 31.4 & \multirow{2}{*}{12.37} & \multirow{2}{*}{$001^{*}$} \\
Right Ear & Control & 28.34 & 9.96 & 12.3 & 45.7 & & \multirow{2}{*}{$023^{*}$} \\
\hline TEOAE & Study & 21.00 & 5.62 & 10.3 & 35.2 & \multirow{2}{*}{5.48} & \multirow{2}{*}{. } \\
Left Ear & Control & 30.05 & 18.48 & 12.3 & 102 &
\end{tabular}

Statistical Method: ANOVA test

TEOAE: Transient evoked otoacoustic emissions

SD: Standard deviation

F: Frequency

P-value.: Significance 
Table 4. Distribution of the DPOAE responses, per ear and group

\begin{tabular}{|c|c|c|c|c|c|c|c|c|c|c|}
\hline \multicolumn{2}{|c|}{ DPOAE SD (RE) } & \multirow{2}{*}{$\begin{array}{c}\text { Mean } \\
12.6\end{array}$} & \multirow{2}{*}{$\begin{array}{c}\text { Median } \\
12.2\end{array}$} & \multirow{2}{*}{$\begin{array}{c}\begin{array}{c}\text { Standard } \\
\text { Deviation }\end{array} \\
4.5\end{array}$} & \multirow{2}{*}{$\begin{array}{c}\text { CV } \\
35 \%\end{array}$} & \multirow{2}{*}{$\begin{array}{c}\text { Min } \\
3.9\end{array}$} & \multirow{2}{*}{$\begin{array}{l}\text { Max } \\
23.4\end{array}$} & \multirow{2}{*}{$\begin{array}{l}n \\
25\end{array}$} & \multirow{2}{*}{$\begin{array}{l}\text { IC } \\
1.7\end{array}$} & \multirow{3}{*}{$\begin{array}{c}\text { P-value } \\
0.301\end{array}$} \\
\hline \multirow{2}{*}{$1 \mathrm{kHz}$} & Study & & & & & & & & & \\
\hline & Control & 11.1 & 12.1 & 5.6 & $51 \%$ & 0 & 19 & 25 & 2.2 & \\
\hline \multirow{2}{*}{$2 \mathrm{kHz}$} & Study & 16.9 & 17.4 & 5.3 & $32 \%$ & 6.6 & 29.1 & 25 & 2.1 & \multirow{2}{*}{0.323} \\
\hline & Control & 18.5 & 18.5 & 6.3 & $34 \%$ & 3.2 & 28.2 & 25 & 2.5 & \\
\hline \multirow{2}{*}{3 kHz } & Study & 15.2 & 15.7 & 6.0 & $39 \%$ & 3.7 & 26.1 & 25 & 2.4 & \multirow{2}{*}{0.655} \\
\hline & Control & 15.9 & 15.6 & 5.4 & $34 \%$ & 6.8 & 29.5 & 25 & 2.1 & \\
\hline \multirow{2}{*}{$4 \mathrm{kHz}$} & Study & 18.5 & 17.9 & 5.6 & $30 \%$ & 6.4 & 29.3 & 25 & 2.2 & \multirow{2}{*}{0.601} \\
\hline & Control & 19.2 & 19.9 & 4.4 & $23 \%$ & 7.3 & 28.2 & 25 & 1.7 & \\
\hline \multirow{2}{*}{$6 \mathrm{kHz}$} & Study & 15.8 & 15 & 6.8 & $43 \%$ & 4.3 & 29 & 25 & 2.6 & \multirow{2}{*}{0.070} \\
\hline & Control & 19.3 & 20.5 & 6.5 & $34 \%$ & 7 & 29.7 & 25 & 2.6 & \\
\hline \multicolumn{2}{|c|}{ DPOAE SD (LE) } & Mean & Median & $\begin{array}{l}\text { Standard } \\
\text { Deviation }\end{array}$ & CV & Min & Max & $\mathbf{N}$ & IC & P-value \\
\hline \multirow{2}{*}{$1 \mathrm{kHz}$} & Study & 10.8 & 10.3 & 5.6 & $52 \%$ & 0 & 23.2 & 25 & 2.2 & \multirow{2}{*}{0.988} \\
\hline & Control & 10.8 & 11.9 & 7.3 & $67 \%$ & 0 & 23.6 & 25 & 2.9 & \\
\hline \multirow{2}{*}{$2 \mathrm{kHz}$} & Study & 16.6 & 17.6 & 6.1 & $37 \%$ & 4.3 & 29.4 & 25 & 2.4 & \multirow{2}{*}{0.757} \\
\hline & Control & 17.2 & 17.4 & 6.9 & $40 \%$ & 4.3 & 30.6 & 25 & 2.7 & \\
\hline \multirow{2}{*}{$3 \mathrm{kHz}$} & Study & 15.5 & 16.5 & 5.4 & $35 \%$ & 6.2 & 28.3 & 25 & 2.1 & \multirow{2}{*}{0.526} \\
\hline & Control & 14.4 & 13.5 & 6.6 & $45 \%$ & 5.2 & 28.6 & 25 & 2.6 & \\
\hline \multirow{2}{*}{$4 \mathrm{kHz}$} & Study & 18.3 & 19 & 6.1 & $33 \%$ & 8.3 & 31.3 & 25 & 2.4 & \multirow{2}{*}{0.923} \\
\hline & Control & 18.1 & 17.6 & 6.4 & $35 \%$ & 6.5 & 32.9 & 25 & 2.5 & \\
\hline \multirow{2}{*}{$6 \mathrm{kHz}$} & Study & 15.9 & 15.4 & 5.8 & $37 \%$ & 6 & 28.8 & 25 & 2.3 & \multirow{2}{*}{0.081} \\
\hline & Control & 18.9 & 21.3 & 6.0 & $32 \%$ & 8 & 29.9 & 25 & 2.4 & \\
\hline
\end{tabular}

Statistical Method: ANOVA test

DPOAE: Distortion Product Otoacoustic Emissions

SD: Standard Deviation

F: Frequency

P-value: significance

There was no statistically significant difference between the groups in relation to the average values of the slope of the DPOAE I/O, from 2,000 to $6,000 \mathrm{~Hz}$ in the right and left ears. There was only a tendency ( $p$ value: 0,085 ) of a smaller value of the slope in the study group in $2 \mathrm{kHz}$ in the right ear.

The average threshold of the growth rates of distortion from $2,000 \mathrm{~Hz}$ to $6,000 \mathrm{~Hz}$ varied from 38 to $42.8 \mathrm{dBSPL}$ with no difference between the groups ( $p$ value greater than 0.05 ).

\section{DISCUSSION}

The most willing and assiduous individuals were those who had been with the drum band for over two years, which may have been a determining factor for the results of the present research. Most individuals did not rehearse for very long with the band: $60 \%$ rehearsed only one day a week and the majority did it for only an hour $(72 \%)$. The greater the rehearsal, in hours, the greater the tendency to present tinnitus. The musicians of the present study with longest time with the band, more days and hours of rehearsal presented greater occurrence of tinnitus. Tinnitus was reported in $23.5 \%$ in the study group and in $27.7 \%$ in the control group, with no statistically significant difference. However, there was a positive correlation of the variable tinnitus with the time in drum band and the rehearsal hours. Workers exposed to noise have predominantly bilateral tinnitus of the "wheezing" kind", more frequently during the night and correlated with the level of noise. The longer the exposure and the higher the level of sound pressure, the greater the occurrence of tinnitus ${ }^{25,26}$. Such results are consistent with the present study, as the musicians who had been longer in the band, and rehearsed for more days and hours presented tinnitus more frequently.

The use of personal stereos, a habit that may be considered a risk to hearing, was found in $78 \%$. Research shows that the excessive use of these devices 
is growing due to urbanization and the advance of technology and it may cause hearing alteration due to the time and loudness of the music and it may even diminish otoacoustic emissions ${ }^{20,22,27,28}$.

Regarding the use of hearing protector, $80 \%$ of the individuals did not use any king of protection despite the sample being composed of Audiology and Speech Therapy students. Thus, awareness campaigns and protection measures should be intensified in the community.

The average levels of sound pressure during the rehearsals were higher than $96 \mathrm{~dB}(\mathrm{~A})$ which could be harmful to hearing. Despite the fact that noise assessment was not the goal of the present investigation, it is worth highlighting that even those who were exposed to high levels, rehearsed for only an hour, in average. Therefore, if we consider the Regulatory Norm 15 of the Brazilian Ministry of Labor and Employment, the daily acceptable level of noise exposure is of 1 hour and 45 minutes $^{29}$. Thus, considering the age of the subjects and the little time of the exposure, we believe that the results obtained in the present study were within the expected.

The permanent change of the hearing threshold may occur due to the continued exposure to loud sounds mainly if there is no rest between the exposure. Noise-induced Hearing Loss (NIHL) is influenced by factors such as: physical characteristics of the noise (type, level of sound pressure and spectrum), exposure time (frequency and hours) and individual susceptibility ${ }^{26,30}$. In the present study, to avoid that even short exposures to high sound levels could influence the results of the testes, procedures were only carried out at least 48 hours since the last rehearsal of the drum bands. Furthermore, we also used as inclusion criterion the presence of type A tympanometric curve to ensure there were no alterations in the middle ear at the time of the exam which might have influenced the results. Thus, the OAE identification was more reliable.

The exposure to noise in industrial workers and or musicians may cause the reduction of the transient and distortion products otoacoustic emissions. In fact, studies have demonstrated that when there are alterations in a third of the external hair cells, the tonal audiometry remains normal with reduction in the OAE which we found in our study. Research has revealed that the greater the exposure to noise, the smaller the response found in the tests, mainly in 4 and $6 \mathrm{KHz}$ (£2) in both ears ${ }^{1,31}$. In the present study, there was a similar result with the reduction of the TEOAE in the group exposed to noise. Furthermore, in the DPOAE, there was a reduction of response in $4 \mathrm{k}$ and $6 \mathrm{kHz}$ (f2) in the study group, in the right ear and a tendency to smaller response of DPOAE in $6 \mathrm{kHz}(\mathrm{f} 2)$. This result was expected, as the literature shows higher incidence of hearing alteration first in the higher frequencies as they are more susceptible, especially in the region between 3 and $6 \mathrm{KHz}$, in individuals exposed to noise ${ }^{1,29,32,33}$.

The average threshold of the growth rate in the DPOAE varied from 38 to $41,8 \mathrm{~dB}$, like those found in the literature ${ }^{5,34,35}$. There was not a statistically significant difference between the two groups. In DPOAEs $\mathrm{I} / \mathrm{O}$, the responses were obtained from 30 to $75 \mathrm{dBSPL}$, being the greatest response in the frequency of $6 \mathrm{kHz}$ (f2) of the right ear, with $75 \mathrm{dBSPL}$, in the study group. The smallest value was obtained with $30 \mathrm{dBSPL}$, in both groups. In the literature, a study obtained the best response in 1000 and $2000 \mathrm{~Hz}$, and $45 \mathrm{dBSPL}$ for 4000 and $5000 \mathrm{~Hz}$ and $70 \mathrm{dBSPL}$ as the highest threshold for all the frequencies under test ${ }^{5}$, similarly to the one reached in our study.

The slope reflects the cochlear non-linearity which decreases with the rise of sound pressure of the stimulus and with cochlear lesion. After the exposure to the noise, the slope may seem more inclined and with smaller values and it may indicate an alteration in the compression mechanism of the external hair cells. In other words, there is a steeper growth rate in cochlear disorder ${ }^{36}$. This pattern was not observed in the present study as the slope values ranged from 0.4 to 1.0 $\mathrm{dB}$, with no difference between the groups. There was only a tendency to smaller values in the study group in the frequency of $2,000 \mathrm{~Hz}$ in the right ear. Such result was also observed in another study which analyzed the growth rate of the emissions in normal-hearing adults with and without tinnitus, identifying higher thresholds in $2,000 \mathrm{~Hz}$ in the group with tinnitus, characterizing the $2,000 \mathrm{~Hz}$ frequency as the most vulnerable ${ }^{16}$. The Slope values obtained in the present study are similar to the ones found in the literature concerning normal-hearing adults whose average values are close to $1 \mathrm{~dB}^{12,37,38}$.

In view of these results, the participants were informed about the importance of the use of earplugs and the deleterious effects of noise to hearing, as well as the importance of audiology monitoring in order to prevent future hearing loss. 


\section{CONCLUSIONS}

Young people exposed to noise presented a lower amplitude of otoacoustic emissions evoked by transient stimulus, when compared to non-exposed ones.

The occurrence of tinnitus correlated with the time of exposure and use of personal stereo, thus, the longer the exposure to noise, the greater the occurrence of tinnitus.

\section{REFERENCES}

1. Borger ME, Sampaio ALL, Oliveira CACP. Emissões otoacústicas evocadas por produto de distorção em trabalhadores normo-ouvintes expostos ao ruído ocupacional. Gestão \& Saúde. 2013;4(2):2065-77.

2. Kemp DT. Stimulated otoacoustic emissions from within the human auditory system. J. Acoust Soc Am. 1978;64(5):1386-91.

3. Berlin CL, Hood LJ, Wen H, Szabo P, Cecola RP, Rigby $P$ et al. Contralateral suppression of non-linear click evoked otoacustic emissions. Hear Res. 1993;71(1-2):1-11.

4. Lopes FO, Carlos R, Thomé D, Eckley C. Emissões Otoacústicas transitória e produto de distorção na avaliação da audição em recém-nascidos com poucas horas de vida. Rev Bras Otorrinolaringol. 1996;62(3):220-8.

5. Tiradentes JB, Coube CZV, Costa Filho OA. Estudo do padrão de respostas das curvas de crescimento (dp growth rate) das emissões otoacústica produto de distorção em indivíduos com audição normal. Rev Bras Otorrinolaringol. 2002;68(1):21-6.

6. Almeida PP, Sanches SGG, Carvallo RMM. Otoacoustic emissions growth rate threshold: distortion product in neonates. Pró-Fono R Atual Cient. 2010;22(4):09-14.

7. Kemp DT. Evidence of mechanical nonlinearity and frequency selective wave amplification in the cochea. Arch otorhinolaryngol.1979;224(1-2):37-45.

8. Gorga MP, Neely ST, Dierking DM, Kopun J, Jolkowski K et al. Low frequency and high-frequency cochlear nonlinearity in humans. J Acoust Soc Am. 2007;122(3):1671.

9. Gates GA, Mills D, Nan B, D'Agostino R, Rubel E. Effect of age on the distortion product otoacoustic emission growth functions. Hear Res. 2002;163(1-2):53-60.

10. Gorga MP, Neely ST, Dorn PA, Hoover BM. Further efforts to predict pure-tone thresholds from distortion product otoacoustic emission input/output functions. J Acoust Soc Am. 2003;113(6):3275-84.

11. Neely ST, Johnson TA, Kopun J, Dierking DM, Gorga MP. Distortion-product otoacoustic emissions input/output in normal hearing and hearing-impaired human ears. J Acoust Soc Am. 2009;126(2):728-38.

12. Campos UP, Carvallo RMM. Correlation between DPOAE I/O functions and pure-tone thresholds. Braz J Otorhinolaryngol. 2011;77(6):754-60.

13. Frota $S$, lório MCM. Emissões otoacústicas por produtos de distorção e audiometria tonal liminar: estudo da mudança temporária do limiar. Rev Bras Otorrinolaringol. 2002;68(1):15-20.

14. Salazar A, Fajardo L, Vera C, García M, Solís F. Comparación de emisiones otoacústicas producto de distorsión en individuos expuestos y no expuestos a ruido ocupacional. Ciencia \& Trabajo. 2003;5(10):24-32.

15. Dorn PA, Konrad-Martin, Neely ST, Keefe DH, Cyr E, Gorga MP. Distortion product otoacoustic emission input/output functions in normal hering and hearing-impaired human ears. J. Acoust. Soc. Am. 2001;110(6):3119-31

16. Sanches SGG, Sanchez T, Carvalho RMM. Influence of Cochlear Function on Auditory temporal Resolution in tinnitus Patients. Audiol and Neurootol. 2010;15(5):273-81.

17. Johnson TA, Neely ST, Kopun JG, Dierking DM, Tan H, Gorga MP. Clinical test performance of distortionproduct otoacoustic emissions using new stimulus conditions. Ear Hear. 2010;31(1):74-83.

18. Jassen $T$. Diagnostocs of the cochlear amplifier by means of DPOAE growth functions. HNO. 2005;53(2):121-33.

19. Sisto R. Modeling the growth rate of distortion product otoacoustic emissions by active nonlinear oscillators. J. Acoust Soc Am. 2004;116(3):32-8.

20. Sanchez TG, Oliveira JC, Kii MA, Freire K, Cota $J$, Moraes FV. Tinnitus in adolescents: the start of vulnerability of the auditory pathways. CoDAS. 2015;27(1):5-12

21. Jerger J. Clinical experience with impedance audiometry. Arch. Otolaryngol. 1970;92(4):311-24.

22. Rocha EB, Azevedo MF, Ximenes Filho JA. Study of the hearing in children born from pregnant women exposed to occupational noise: Assessment by distortion product otoacoustic emissions. BJORL. 2007;73(3):359-69. 
23. Finitzo T, Albright K, Oneal J. The newborn with hearing loss: detection in the nursery. Pediatrics. 1998;102(6):1452-60.

24. Gorga MP, Neely ST, Ohlrich B, Hoover B, Redner J, Peters J. From laboratory to clinic: a large scale study of distortion product otoacoustic emissions in ears with normal hearing and ears with hearing loss. Ear \& Hearing. 1997;18(6):440-55.

25. Steinmetz LG, Zeigelboim BS, Lacerda AB, Morata TC, Marques JM. The characteristics of tinnitus in workers exposed to noise. BJORL. 2009;75(1):7-14.

26. Harger MRHC, Barbosa-Branco A. Efeitos auditivos decorrentes da exposição ocupacional ao ruído em trabalhadores de marmoraria no Distrito Federal. Rev Ass Med Bras. 2004;50(4):396-9.

27. Luz TS, Borja ALF. Sintomas auditivos em usuários de estéreos pessoais. Int. Arch. Otorhinolaryngol. 2012;16(2):163-9.

28. Barcelos DD, Dazzi NS. Effects of the MP3 player on hearing. Rev. CEFAC. 2014;16(3):779-91.

29. Negrão MA, Soares E. Variation in amplitudes of evoked otoacoustic emissions and suceptibility to hearing loss induzed by nois-hlin. Rev. CEFAC. 2004;6(4):414-22.

30. Pinto AS, Cunha LJP, Santos LDS, Távora EMM, Filho JSCS, Toguchi LN et al. O ruído urbano e a saúde auditiva. Lato \& Senso. 2002;3(5):90-3.

31. Monteiro VM, Samelli AG. Estudo da audição de ritmistas de uma escola de samba de São Paulo. Rev Soc Bras Fonoaudiol. 2010;15(1):14-8.

32. Maia JRF, Russo ICP. Study of the hearing of rock and roll musicians. Pró-Fono R Atual. Cient. 2008;20(1):49-54.

33. Teles RM, Medeiros MPH. Perfil audiométrico de trabalhadores do distrito industrial de Maracanaú - CE. Rev Soc Bras Fonoaudiol. 2007;12(3):233-9.

34. Sanches SGG. Função coclear e resolução temporal em indivíduos com zumbido. [Tese] São Paulo (SP): Universidade de São Paulo; 2008.

35. Coube CZV, Costa Filho OA. Emissões otoacústica evocadas: produto de distorção em indivíduos com audição normal. Rev Bras Otorrinolaringol. 1998;64(4 pt1):33-45.

36. Lonsbury-Martin BL, Martin GK, Telischi FF. Emissões otoacústicas na prática clínica In: Musiek FE e Rintelmann WF. Perspectivas atuais em avaliação auditiva. São Paulo: Manole, 2001. p.163-92.

37. Gehr DD, Janssen T, Michaelis CE, Deingruber K, Lamm K. Middle ears and cochlear disorders results in different DPOAE growth behavior: implications for the differentiation of sound conductive and cochlear hearing loss. Hear Res. 2004;193(1-2):9-19.

38. Buzo BC. Emissões otoacústicas produto de distorção: estudo da função de crescimento em indivíduos com limiares audiométricos normais. [dissertação] São Paulo (SP): Pontifícia Universidade Católica de São Paulo; 2007. 